\title{
Fluidez tectónica. As bio-tecno-ciências, a bio-arte e a paisagem cognitiva do presente
}

Tectonic fluidity. Bio-techno-sciences, bio-art, and the cognitive landscape of the present

Fluidité tectonique. Les bio-techno-sciences, le bio-art et le paysage cognitif du présent

Luís Quintais

\section{(2) OpenEdition}

\section{Journals}

Edição electrónica

URL: http://journals.openedition.org/rccs/726

DOI: $10.4000 /$ rccs. 726

ISSN: 2182-7435

\section{Editora}

Centro de Estudos Sociais da Universidade de Coimbra

\section{Edição impressa}

Data de publição: 1 Dezembro 2007

Paginação: 79-94

ISSN: 0254-1106

\section{Refêrencia eletrónica}

Luís Quintais, «Fluidez tectónica. As bio-tecno-ciências, a bio-arte e a paisagem cognitiva do presente », Revista Crítica de Ciências Sociais [Online], 79 | 2007, colocado online no dia 01 outubro 2012, criado a 21 abril 2019. URL : http://journals.openedition.org/rccs/726 ; DOI : 10.4000/rccs.726 


\section{LUÍS QUINTAIS}

\section{Fluidez tectónica. As bio-tecno-ciências, a bio-arte e a paisagem cognitiva do presente'}

O presente ensaio constitui um comentário crítico à tese de Paul Virilio de que certo tipo de práticas na fronteira entre a arte e a tecno-ciência, práticas a que se convencionou chamar "bio-arte", epitomizam o radicalismo expressionista e niilista do presente. A investigação aqui iniciada revela, através de um olhar sobre as práticas artísticas de Eduardo Kac, que estas, longe de apelarem a tal radicalismo, só se tornam operativas e significativas numa atmosfera de compromisso ético e político que é tomada como inescapável dada a relevância que assumem as bio-tecno-ciências no mundo contemporâneo.

[T] he center cannot bold

W. B. YEATS

\section{Quando a arte se torna perigosa ou a invectiva de Paul Virilio}

Num ensaio publicado originalmente no ano 2000, Paul Virilio concentrava-se na radicalização de certos sectores das ciências e das artes, acusando-os de "impiedade", uma impiedade que teria, aliás, caracterizado todo século XX, a glosar a citação que o filósofo e urbanista francês faz de Albert Camus na abertura do seu texto: "Este impiedoso século, o vigésimo" (apud Virilio, 2003: 27).

Virilio caracteriza as novas formas de "expressionismo" que parecem espreitar por entre o som e a fúria do presente, e que aliam arte e ciência (melhor seria dizer tecno-ciência) no dealbar do século XX (Virilio, 2003: 49-51).

\footnotetext{
${ }^{1}$ Uma versão deste ensaio foi apresentada no âmbito do seminário Discurso, Legitimación, Memoria no dia 31 de Maio de 2007 às 18 horas, Sala de Juntas de La Facultad de Filología, Universidade de Salamanca, Salamanca, Espanha. Agradeço a todos os comentários críticos que aí me foram feitos, e, em especial, a Pedro Serra pelo convite, hospitalidade e generosidade. Agradeço ainda as sugestões de clarificação que foram feitas pelos revisores científicos da RCCS. É óbvio que todas as eventuais incorrecções são da minha responsabilidade.
} 
A imprecisão da fronteira entre arte e tecno-ciência reside afinal numa "flagrante exibição do horror" (ibid.: 50). Transversal à arte e à tecno-ciência do presente estaria a sua pulsão niilista, que Virilio não define de forma precisa, mas que poderíamos, dado o contexto, tomar como uma "vontade" de rasura sem precedentes, e que, na acepção expressionista a que Virilio recorre, denunciaria o seu radicalismo através da tentativa de recomposição integral das formas naturais, em particular as do corpo humano. Sem dúvida que Virilio, neste ponto, faz articular tacitamente (sem explicitação de maior, pois) certos sectores da arte contemporânea com as "vanguardas" dos alvores do século XX que, como sabemos, mantiveram complexas relações com a técnica e, em particular, com a guerra (a guerra moderna, onde a possibilidade de impiedosa rasura através da técnica se tornou uma possibilidade), relações que, em muitos casos, evidenciam um consentimento perturbador. Veja-se, por exemplo, a celebração da guerra pelos futuristas italianos (v.g., Marcus, 1999: 259), ou aquilo que Grail Marcus nos diz sobre os dadaístas:

Quando Ball escrevia acerca da necessidade de apagar tudo o que tinha sido escrito antes, quando Tzara dizia que não lhe interessava saber se alguém tinha existido antes dele, quando Huelsenbeck entoava "O Fim do Mundo", os dadaístas alimentavam-se desse impulso, mesmo se a sua aversão ao que sobrava disso os trouxesse de novo à vida. Dadá, tal como o próprio século, era o direito a mijar e cagar às cores: branco, amarelo, preto e vermelho. Por mais de uma vez, nos primeiros anos do regime nazi, a Gestapo procurou Huelsenbeck (É aqui que mora o dadaísta Huelsenbeck? Não, respondia a sua mulher, aqui mora o dr. Huelsenbeck, médico); a salvo nos Estados Unidos, ele jamais se cansou de citar o discurso de Nuremberga, de 1936, no qual Hitler chamou a Dadá lama mal cheirosa, o que provava o inocente poder de Dadá. Mas não é difícil de concluir que Hitler, ele próprio conhecedor dos meios boémios e também pintor e artista, combateu Dadá durante tanto tempo e tão duramente porque Dadá o tocara, porque sentira a sua força, do mesmo modo que Ball sentira o niilismo de Parole in Libertà, de Marinetti, ou Siurlai o sopro da morte na "Glória a Deus”, de Hennings, e Huelsenbeck a excitação de uma possível ordem total em “O que é o dadaísmo e que deseja ele para a Alemanha?”. (Marcus, 1999: 280-281)

Virilio abastece-se desta suposta solução de continuidade entre o radicalismo estético das primeiras décadas do século XX e os desígnios (para ele imensamente suspeitos) do enlace arte/tecno-ciência a que assistimos contemporaneamente. Familiarizados com formas radicais de desporto em que os atletas arriscam a própria vida em nome de uma performance destituída de sentido, começamos agora a assumir formas radicais de tecno-ciência, em que se corre "o risco supremo de desnaturalizar o ser 
vivo - tendo já destruído o seu meio ambiente" (Virilio, 2003: 51). Neste sentido, o extremar de certas formas de arte, como sejam as "práticas transgénicas", não se destina senão a fazer embarcar a biologia numa espécie de "expressionismo" em que a teratologia deixou de ser simplesmente o estudo de malformações, tornando-se antes uma demanda pela sua "reprodução quimérica" (ibid.: 51). Ou seja, Virilio sugere-nos que as bio-tecno-ciências abrem a porta a um mundo de recomposição tecno-selectiva das formas naturais movido já não por desígnios de demonstração, mas antes de "monstração". Formas "melhoradas" por critérios expressivos que se reproduzirão inevitavelmente.

A argumentação de Virilio merece ser largamente matizada. ${ }^{2}$ Tais formulações prendem-se com a dramatização das relações entre arte e tecno-ciência. Essa dramatização consiste numa aposta em que exemplos extremos só muito esparsamente invocados são tomados como sintomáticos do que poderá ser o sentido amplo das relações entre arte e tecno-ciência. O exemplo mais espectacular desse enlace é, sem dúvida, o da intitulada "arte transgénica”. A designada arte transgénica é, para já, e tão-só, uma província da "bio-arte" (qualquer forma de arte inspirada nas bio-tecno-ciências), e uma província que, seguramente, a apoiarmo-nos no seu mais destacado cultor (e estou a falar aqui de Eduardo Kac), não promove de modo óbvio o drama viriliano do expressionismo tecno-científico e suas extensões artísticas. O grande problema é, em meu entender, outro, com implicações mais gerais, que o trabalho de Eduardo Kac, afinal um dos alvos de Virilio, amplifica.

Talvez a arte e a nossa percepção do que ela é estejam ainda demasiadamente comprometidas com uma ideia de centro ou essência de que a "estética” será porventura a categoria mais equívoca e, talvez, a mais desnecessária. Assim, o meu filistinismo metodológico - um filistinismo que recebo do antropólogo Alfred Gell (1998, 1999) - diz-me que o grande problema radica na ausência de um eixo ou de um fundamento a partir do qual as produções culturais do presente possam ser medidas. É assim que devemos ler o pensamento de Virilio sobre a arte contemporânea. Diz-nos ele em conversa com Sylvère Lotringer (2005):

O fim da capacidade para fazer convergir associa-se ao movimento, à desterritorialização. A arte deixa de ter um fundamento. [...] Escrevi sobre o buraco negro da arte, o facto de a arte não mais ser localizada. [...] Esta deslocalização é uma incapacidade para fazer convergir. Perdemos perspectiva no sentido amplo, não no sentido

${ }^{2}$ Para uma resposta a Virilio articulada no interior do campo da designada "bio-arte", ver, v.g., Catts e Zurr (2007). 
do Quatrocento. Há um apagamento da perspectiva e, assim, um colapso do sentido. A meu ver, a perspectiva é indispensável ao conhecimento. Porque orienta, confere um sentido de direcção. (Lotringer e Virilio, 2005: 83-84)

Vivemos num mundo sem um eixo, pois, mas insistimos nesse eixo (tal como faz Virilio). Insistimos no centro e na essência porque sem eles uma espécie de dissonância alarmante parece fazer soçobrar a possibilidade de redenção pelo sentido. Este é, sem dúvida, um aspecto decisivo do apuro contemporâneo. Assim, se quiséssemos mapear a paisagem cognitiva do presente, movimento sem o qual não é possível compreender aquilo a que se chama bio-arte, teríamos de tomar em linha de conta que a deriva de categorias e a sua integral reconfiguração, sendo um inquietante dado dessa paisagem, têm um lastro histórico considerável que, a partir da segunda metade do século XX, com a emergência da genética molecular, da teoria da informação e das possibilidades de manipulação e transformação tecnológica da "natureza", se torna perceptível. ${ }^{3}$ Torná-lo perceptível no espaço público, tal como fazem artistas como Kac, não será, em si mesmo, multiplicar o perigo que tal deriva faz supor. $\mathrm{O}$ que a bio-arte tem vindo afinal a realizar (a existir um campo de práticas comuns de que se reclamam os seus oficiantes) é uma recontextualização pública (e, nesse sentido, ética e política) do perigo que nos espreita e que não pode ser escamoteado. Se Virilio nos diz que a arte, em associação com a tecno-ciência, se tornou perigosa, melhor seria talvez dizer que a arte se tornou um locus de reflexividade e avaliação do "acidente", esse "milagre profano", a usar a magnífica expressão de recorte benjaminiano que Virilio usa nas suas conversas com Sylvère Lotringer (2005: 63). Para Virilio, a tecnologia faz supor o acidente, como se de um potencial escondido se tratasse. Assim, por exemplo, a invenção da locomotiva contém em si mesma a invenção do descarrilamento. O acidente é, para Virilio, a afirmação de uma negatividade que se faz inscrever na modernidade e no seu projecto de progresso científico. $\mathrm{O}$ acidente é, nesse sentido, um elemento de diagnóstico ou, a usar a declinação escatológica cara a Virilio, um elemento de revelação, e daí a o alcance da expressão “milagre profano" a que faz apelo (ver, também, Derian, 1998: 20-21).

\footnotetext{
3 A expressão "paisagem cognitiva do presente" é uma citação transformada de Bradd Shore (1996: 73) quando se reporta à "paisagem cognitiva da modernidade". Prefiro aqui a expressão "do presente", de modo a evitar uma enunciação precisa daquilo em que consiste a "modernidade", ainda que, ao longo do meu texto, seja evidente a importância que confiro à modernidade não de um ponto de vista estritamente cronológico, mas antes tomando-a como uma "tonalidade" ou "atmosfera" que se prende com a nossa percepção do que é a racionalidade tecno-científica, suas extensões, implicações, e riscos. Pressupõe-se, pois, que este presente é caracterizado por um mundo que está dentro da tecno-ciência, e não o contrário.
} 
O quadro em que vivemos (e que excede em muito as práticas dos artistas envolvidos no campo da bio-arte) é, basicamente, o seguinte: se os humanos são veículos de informação genética e cultural, as bio-tecno-ciências vêm dar um sentido insuspeito à humana singularidade de nos reconhecermos como veículos dotados de desígnios que não se conformam a uma mera replicação genética ou cultural. Como afirma Keith Stanovich (2004) num livro recente inspirado em Richard Dawkins (1976), somos veículos humanos ou "robôs" que, incapazes de nos submetermos às lógicas cegas da replicação genética e cultural, promovemos formas de "rebelião" a tais lógicas cegas. Tais veículos humanos - todos nós, afinal - encaminham-se para a reconfiguração das suas disposições e constrangimentos (aparentemente incontornáveis) de replicação genética e cultural. De modo particularmente importante para o meu argumento, Stanovich acrescenta que a engenharia genética e a terapia genética representam talvez o último triunfo das máquinas de sobrevivência de Dawkins: "Com a tecnologia de engenharia genética, nós, que fomos construídos pelos replicadores para servir como as suas máquinas de sobrevivência, usamo-los para os nossos próprios fins - fins que não são os fins dos genes [...]" (2004: 280). É evidente que há na afirmação de Stanovich uma declinação fáustica que merecerá certamente ponderação. Porém, ela revela-nos certeiramente o perfil inquietante do presente.

Neste sentido, uma das acepções do presente seria a de um mundo onde esta reconfiguração se afiguraria de tal forma profunda que solicitaria a criação de formas generalizadas de reflexividade, formas que poderiam ser (e são) potenciadas pelas práticas artísticas dos bio-artistas.

\section{Fluidez tectónica}

É certo que, neste cenário de transgressão tecnológica, as tonalidades utópicas depressa se tornam enfaticamente distópicas. E tal acontece porque tais tonalidades, destituídas de mecanismos de regulação, poderão conduzir-nos à mais desconcertante fluidez tectónica de que há memória. Isto a pedir de empréstimo um termo, "tectónica", que procede da geologia, mas também da arquitectura, e que nos chama a atenção para aspectos estruturais da natureza e da cultura. De algum modo, a palavra tectónica assume como trunfo ou valência semântica não negligenciável a impossibilidade de destrinça natureza/cultura. Refuto o valor absoluto desta destrinça, procurando, justamente, ter em atenção o modo como se revelam e se expressam estruturas e funções tectónicas e como se reinventam tecno-cientificamente tais estruturas e funções.

Esta fluidez tectónica a que me refiro resultará do facto de as bio-tecno-ciências colocarem em causa a estabilidade ontológica daquilo que se 
denomina "tipos naturais". O que as bio-tecno-ciências nos sugerem é a possibilidade de um mundo em que qualquer "teoria das essências" (D’Andrade, 1995: 176-178) poderá ficar radicalmente comprometida. A assumir que tais teorias fazem supor a implícita existência de tipos naturais, o que as bio-tecno-ciências promovem é um mundo sem eixo ontológico e morfológico, um mundo em que a tectónica dos tipos naturais fica ou poderá ficar seriamente ameaçada, um mundo onde a presença de "tecno-tipos" teria de ser seriamente ponderada. Para fundamentar melhor o que estou aqui a argumentar, leia-se o seguinte fragmento de um estudo de Eleanor Rosch, que reivindica a estabilidade de certas correlações na nossa relação com o mundo:

Os objectos materiais do mundo são percebidos como possuindo alta correlação estrutural. Ou seja, dado um sujeito que percebe os atributos complexos de penas, pêlo, e asas, é um facto empírico fornecido pelo mundo percebido que asas coocorrem com penas mais do que com pêlo. E... é um facto do mundo percebido que é mais provável objectos com os atributos perceptivos de cadeiras terem a potencialidade funcional de sentar do que objectos com a aparência de gatos. (apud D’Andrade, 1995: 116)

Neste mundo em que o bricolage biotecnológico e evolutivo se tornará prática corrente, a ausência de eixo que identifiquei ganha certamente atribuições novas. Sendo assim, as "altas correlações estruturais" em que se fundam as ontologias tal como as percepcionamos e reconstruímos cognitivamente poderão ser radicalmente revistas e reinventadas, sendo que asas poderão co-ocorrer mais com pêlo do que com penas, entre outras "bizarrias" igualmente prováveis. Esse fundo tectónico constituído por tipos naturais poderá ser radicalmente reconfigurado, sendo que tal reconfiguração será também perceptiva e cognitiva. Neste território, as correlações "obrigatórias" de outrora serão pulverizadas. Estamos perante uma turbulência configuracional da qual começamos a dar-nos conta, hoje.

É esta reconfiguração radical eventualmente inexorável que vem exigindo do presente formas de multiplicação da reflexividade. E esta reflexividade é, se quisermos, um dispositivo decisivo para a possibilidade de constituição de mecanismos de regulação e auto-regulação sem os quais os produtos de uma eventual deriva biotecnológica e suas implicações poderão ser perigosamente afastados do espaço público e exclusivamente submetidos a desígnios e transacções de laboratório. Sendo um dos traços do presente, a multiplicação da reflexividade implica formas de pensamento/acção que se apoiam em metáforas e em estratégias de investigação que julgámos um dia 
divergentes e que, afinal, o não são de todo. Ou seja, a constatação contemporânea da hibridez de formas de pensamento/acção vem pôr em causa a compartimentação e improvável contacto entre modos de conhecer e agir em que se fundaria a modernidade (Latour, 1991). Estou a apelar aqui a que consideremos a hipótese de domínios que se intersectam produzindo efeitos na nossa percepção do presente. E, para identificarmos os planaltos e singularidades em que se intersectam, nada melhor do que estarmos atentos aos processos de contaminação semântica e instrumental que mutuamente alimentam arte e tecno-ciência, isto é, atentos à recursividade de sentidos e de técnicas que se estabelece entre domínios tomados vulgarmente como não recursivos.

E é aqui que se instala o que se designa hoje por bio-arte. Tratando-se de um campo de propostas muito diferenciadas, o que elas têm em comum é talvez um desígnio político: mostrar como noções de "vida" ou de "informação" (noções que no contexto em apreço são decisivas, e às quais voltarei adiante) merecem ser "dobradas", "com-plicadas", no sentido deleuziano do termo (Deleuze, 1988).

Ao dizer isto, estou a argumentar que a bio-arte assenta numa concepção topológica dos domínios arte/tecno-ciência em que o "interior" está em contacto com o "exterior", e em que os fluxos, intersecções e trânsitos entre domínios devem ser apreciados, sob pena de não compreendermos a densidade histórica dos problemas levantados, e sob pena também de muito do que se passa no interior dos laboratórios se manter perigosamente arredado do espaço público, dada a pretensa neutralidade dos projectos que aí decorrem. Poderíamos dizer que a concepção topológica do conhecimento, que me parece notória quando nos confrontamos com figuras como Kac, está patente no modo como José Luís Garcia, sustentando a sua argumentação em Abraham Moles, faz da bio-arte um sintoma da "expansão do fenómeno de meta-criação":

Esta renovação da arte tem vindo a realizar-se por via das "artes computacionais", das "artes digitais", da "ciber-arte", da "bio-arte" ou da "arte transgénica”, todas elas integrando o que podemos designar por "artes da informação" ou "info-artes”. O movimento das novas artes no campo da biotecnologia reclama levantar questões acerca dos procedimentos operatórios das tecno-ciências da vida e promover o debate em torno dos seus riscos, incertezas e consequências. A arte estaria, desta forma, a retomar uma vocação que sempre teve - a de explorar, reflectir e criticar os desenvolvimentos da época e da sociedade em que é criada. A arte poderia inserir-se, assim, no contexto alargado das correntes de pensamento sobre as relações entre ciência, tecnologia, e sociedade, pondo em questão a ideia da absoluta neutralidade 
do empreendimento científico. Na sua forma específica, a arte participaria nos dilemas de biologia filosófica e nos debates em torno de como habitar sabiamente o nosso mundo e do futuro da condição humana. (Garcia, 2007: 95)

É neste quadro que poderemos certamente aceder às práticas de Kac, que será aqui usado como um exemplo maior desta complexidade a que Virilio permanece insensível.

\section{Eduardo Kac ou a arte transgénica como exemplo}

Eduardo Kac merece, a este respeito, um olhar atento, porque ele é, indubitavelmente, um dos visados pela crítica acerba de Paul Virilio (ainda que este nunca refira abertamente o seu nome), e também porque se trata de um caso extremo (onde o radicalismo programático e performativo poderia conduzir-nos a uma apressada atribuição de niilismo expressionista ao jeito de Virilio).

O percurso de Kac é muito conhecido e extensamente comentado (inclusivamente pelo próprio), pelo que me abstenho de fazer aqui qualquer exegese de carácter biográfico. ${ }^{4}$ Importa, porém, salientar que esse percurso se encontra fortemente associado a um trabalho de constante investigação das noções de "informação" e "vida" e suas mútuas articulações e espaços intersticiais. Ao longo do seu percurso, Kac escreve e desenvolve projectos sobre "bio-semiótica", "bio-telemática”, e "bio-robótica" (Kac, 2005: 218). Não é possível compreender o seu trabalho se não fizermos apreciações mais contextuais, que nos permitam apreciar a emergência daquilo que Garcia designa por "info-artes". E, para o percebermos, nada melhor do que reportarmo-nos ao conjunto de textos reunidos em Genesis. Life at the End of the Information Age (Gomart, 2007).

Trata-se de um conjunto de textos reunidos em torno de "Genesis", uma exposição que decorreu entre 14 de Abril e 12 de Agosto de 2007 no Centraal Museum de Utrecht comissariada por Emilie Gomart. "Genesis" explorava a história das relações entre tecno-ciência e arte tendo por eixo as noções de "informação" e "vida". A tese explorada era, basicamente, a seguinte: a "informação" moldou o século XX. Tornou manuseáveis problemas complexos. Como escreve Gomart (2007: 9), antes da informação, os engenheiros que procuravam melhorar a transmissão de sinais tinham de pressupor problemas de comunicação específicos a cada meio: televisão, rádio, computador, telefone. Foi o matemático Claude Shannon que simplificou o que se afigurava à partida intratável, escrevendo em "A Matematical

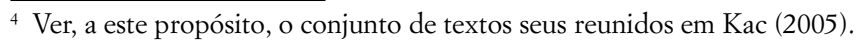


Theory of Communication", um texto de 1948, que o "problema fundamental" da comunicação era o de "reproduzir num ponto uma mensagem seleccionada noutro ponto" (apud Gomart, 2007: 9). Tal mensagem era codificada em "informação" considerada como "uma sequência específica de sinais", sequência que era emitida e recebida. Segundo Gomart, a partir do momento em que se construiu a teoria da informação, os engenheiros passaram a concentrar-se apenas na "eficiência do processo de transferência de informação". Não era já necessário entrar em linha de conta com a diversidade de problemas associados aos diferentes suportes: televisão, rádio, computador, telefone. A informação passava a ser abstracta e eminentemente não contextual. Isto teve um enorme impacto em campos muito diversos, de que são exemplos a linguística, a psicologia, a neurologia, a cibernética, a robótica, e a arte, entre outros. Esta concepção de informação haveria de estar presente na descrição do que fazem os genes, e exigir uma reconceptualização (uma verdadeira "re-codificação") do que é a "vida". Um gene poderia passar a ser definido como uma mensagem capaz de sobreviver à morte do indivíduo e ser recebido por diversas gerações de organismos.

Uma linha paralela haveria de ser traçada entre engenheiros e biólogos dos meados do século XX interessados em sequências de código (binário, molecular) e artistas interessados em séries, alguns influenciados pela leitura de Abraham Moles que José Luís Garcia (2007) cita no seu ensaio. E dir-se-ia que este universo de referências e de modos de conceptualizar a informação e a vida-como-informação, que emerge em meados do século XX, vem também ao encontro das pretensões de movimentos de vanguarda das primeiras décadas do século XX que revelam afinidades electivas com a eficiência e a economia dos modelos dos teóricos da informação e da biologia molecular que lhes sucedem no tempo. Construtivismo, De Stijl, ou Bauhaus servem como referências incontornáveis disso mesmo, e sugerem-nos pistas para pensarmos tudo isto a uma escala mais profunda ainda.

Kac só pode ser compreendido à luz do contexto que Gomart circunscreve (ou à luz de um contexto ainda mais amplo, como aquele que é por mim sugerido no parágrafo anterior). Porém, Kac pretende ainda, a par de propostas recentes de que a exposição "Genesis" deu notícia, complexificar este cenário, revelando os limites do reducionismo que imperou na emergência das concepções de informação" e vida-como-informação de meados do século XX. De algum modo, aquilo que foi "dobrado" tem de ser "desdobrado" novamente, e o "ruído" ou o "contexto" que os teóricos da informação eliminaram, ao destacarem a "total eficácia da mensagem codificada" (Gomart, 2007: 14), teve de ser retomado. Eé isso que artistas como Eduardo Kac nos devolvem: o "ruído", o "contexto". 
Porém, para Virilio, esta complexidade do trabalho de Kac afigura-se inexistente, já que segundo ele, Kac embarca tão-só e sem reservas no projecto de recomposição categorial através dos usos que faz das biotecnologias no seu trabalho. Seria eventualmente isso que estaria patente na proposta de Kac de uma "arte transgénica". Guiando-me pelas suas palavras, Kac parece subscrever o projecto expressionista de rasura e reconfiguração biotecnológica a que se reporta Virilio. Diz-nos ele:

A arte transgénica, proponho eu, é uma nova forma de arte baseada no uso de técnicas de engenharia para criar seres vivos únicos. Isto pode ser conseguido transferindo genes sintéticos para um organismo, através da mutação dos genes de um organismo, ou pela transferência de material genético natural de uma espécie para outra. A genética molecular permite ao artista manipular os genomas de plantas e animais e criar novas formas de vida. (Kac, 2005: 236)

Mas, logo, a seguir reclama para a arte transgénica uma dimensão reflexiva (ele "com-plica" como diria eventualmente Deleuze) que exige dos "observadores" um olhar fortemente envolvido:

A natureza desta nova arte é definida, não apenas pelo nascimento e desenvolvimento de uma nova planta ou animal, mas acima de tudo pela natureza da relação entre artista, público e organismo transgénico. Organismos criados no contexto da arte transgénica podem ser levados para casa pelo público para crescerem no quintal ou ser criados como companheiros dos humanos. Com pelo menos uma espécie em risco a extinguir-se todos os dias, sugiro que os artistas possam contribuir para aumentar a biodiversidade global através da invenção de novas formas de vida. Não há arte transgénica sem responsabilidade e um firme compromisso para com a nova forma de vida assim criada. As preocupações éticas são salientes em qualquer obra de arte, e tornam-se mais cruciais do que nunca no contexto da bio-arte. (Kac, 2005: 237)

O que perturba é o modo como a estabilidade das ontologias e partições entre o humano e o animal, o cultural/tecnológico e o natural, é axiomaticamente rasurada. Ou seja, Kac parte do princípio de que estas fronteiras foram postas em causa através dos usos recentes, via engenharia genética, das bio-tecno-ciências. Parte do princípio de que este processo é inexorável. Uma vez aberta a caixa de Pandora, há que aprender a viver com ela destapada. Se quisermos, a sua posição não anda muito longe daquela que é veiculada por um pensador como Peter Sloterdijk (2007).

Sabendo-se que uma das acepções mais entranhadas de arte é a de que ela serve os interesses da contemplação/fruição lúdica ou mercantil (o que 
é uma forma de a domesticar e neutralizar ética e politicamente), o que perturba é que alguém se aproprie artisticamente da rasura das consabidas ontologias e partições entre o humano e animal, o cultural/tecnológico e o natural. Kac dá continuidade ao projecto de recomposição destas fronteiras, recusando a trivialização da arte.

O que perturba é que alguém, no limite, manipule noções tão decisivas como as de vida e de informação, fazendo-as deslocar, através de uma mediação biotecnológica, para o interior das práticas artísticas.

O que perturba é que alguém dê como adquirida a inoperância de uma concepção do humano que o torna anterior à tecnologia. Mais uma vez, uma semelhança com o trabalho de Peter Sloterdijk.

Que alguém tome como conhecimento tácito do seu trabalho de pesquisa e criação de objectos uma perspectiva que, a vários títulos, poderíamos considerar como pós-humana (justamente porque recusa uma definição heideggeriana do humano como uma essência que precede a técnica), eis aquilo que se afigura ameaçador e a merecer denúncia.

Mas este espaço é tudo menos um espaço ética e politicamente rarefeito, como poderemos ser levados a crer se aceitarmos a invectiva de Virilio. Kac faz situar as suas práticas artísticas num universo onde a implicação de cada um dos intervenientes é parte integrante da atmosfera que pretende criar. Se quisermos, a implicação dos intervenientes é um elemento muito significativo do ambiente das suas criações. Para compreendermos isto, dou apenas dois exemplos do que é a arte transgénica e do sentido que Kac lhe quer imprimir.

Genesis (1998-99). Trata-se do primeiro trabalho de arte transgénica de Kac. Ele adapta uma frase do texto bíblico - "Génesis", 1: 26 ("Let man have dominion over the fish of the sea and over the fowl of the air and over every living thing that moves upon the earth") - traduzindo-o, num primeiro momento, em código Morse, e, num segundo momento, através de um "princípio de conversão", em código ADN. ${ }^{5}$ Kac solicitou a um laboratório que lhe sintetizasse as sequências genéticas conformes à informação traduzida e fez implantar tais sequências numa bactéria não identificada, cultivando-a depois em placas de petri. Uma destas placas de petri foi colocada numa caixa sob uma luz UV que poderia ser activada

\footnotetext{
${ }^{5}$ Em que o traço (-) tem o valor de $\mathrm{T}$, o ponto (.) o valor de $\mathrm{C}$, o espaço entre palavras o valor de A, e o espaço entre letras o valor de G (ver Kac, 2005: 250). Não traduzi o fragmento do texto bíblico apresentado por Kac em inglês por razões que se prendem evidentemente com as dinâmicas de tradução internas à instalação de Kac. Seja como for, citaria aqui uma versão do texto bíblico para português que lhe corresponde: "Dominai sobre os peixes do mar, sobre as aves dos céus e sobre todos os animais que se movem na terra" (Costa, 1991: 18).
} 
por observadores situados em qualquer parte do globo através da web. Escreve Kac:

No contexto do trabalho, a capacidade para alterar a frase é um gesto simbólico: significa que não aceitamos o seu sentido na forma herdada e que novos sentidos surgem à medida que procuramos alterá-la. Usando o mais pequeno gesto do mundo on-line - o clic - os participantes podem modificar a configuração genética de um organismo situado na remota galeria. Esta circunstância única torna evidente, por um lado, a eminente facilidade com que a engenharia genética influencia o mais vulgar nível da experiência. Por outro lado, destaca a condição paradoxal do leigo na idade da biotecnologia. Clicar ou não clicar não é apenas uma decisão ética mas também uma decisão simbólica. Se o participante não clicar, ele permite que a frase bíblica se mantenha intacta, preservando o seu sentido de domínio. Se ele clica, altera a frase e o seu sentido mas não sabe que novas versões poderão surgir. Em ambos os casos, o participante enfrenta um dilema ético e é envolvido no processo. (Kac, 2005: 251-252; sublinhados meus)

Ou seja, e invertendo os termos de Kac, não se trata apenas de uma decisão simbólica, mas também de uma decisão com um valor ético insofismável. De algum modo, o que aí se consagra é a impossibilidade de escapar à participação ética, seja qual for a resposta.

Sem a densidade reflexiva e pública, logo ético-política, em que se fazem inscrever os trabalhos de Kac e a sua recepção (a sua dimensão "dialógica", a usar uma matriz conceptual que lhe é cara) o sentido de tais trabalhos não poderá ser avaliado com propriedade. ${ }^{6}$

Um outro exemplo que reforça este aspecto pode ser encontrado em Alba (2000). Trata-se, muito provavelmente, do seu trabalho mais conhecido. Kac, em colaboração com um laboratório francês, criou uma coelha GFP (Green Fluorescent Protein), isto é, uma criatura à qual se implantou um gene que expressa uma proteína fluorescente sequenciada e clonada a partir da medusa Aequorea victoria. Não possuindo qualquer pigmentação, sob condições ambientais vulgares, Alba era uma coelha branca com olhos cor-de-rosa. Ela apenas se tornava fluorescente quando iluminada com a "luz correcta". 7 A primeira fase do projecto GFP Bunny chegou ao fim em Fevereiro de 2000 com o nascimento de Alba em Jouy-en-Josas (França).

\footnotetext{
${ }^{6}$ Ver, v.g., as suas remissões para Mikhail Bakhtin e Martin Buber em "Negotiating Meaning: The Dialogic Imagination in Electronic Art” (Kac, 2005: 103-123).

7 "Quando (e apenas quando) iluminada com luz azul (excitação máxima a $488 \mathrm{~nm}$ ), ela brilha com uma luz verde claro (emissão máxima a $509 \mathrm{~nm}$ ). É imperativo usar um filtro especial amarelo para ver o brilho." (Kac, 2005: 266).
} 
O que se realizou com a colaboração científica do zoo-sistematizador Louis Bec e dos cientistas Louis-Marie Houdebine e Patrick Prunet. O nome de Alba foi escolhido por Kac, pela sua mulher Ruth, e pela sua filha, Miriam. A segunda fase do projecto consistiu, segundo Kac (2005: 266), no "debate" então "em curso", que se iniciou com o anúncio público do nascimento de Alba a 14 de Maio de 2000 no contexto da conferência Planet Work em São Francisco. A terceira fase haveria de ter lugar quando a coelha fosse viver com Kac em Chicago, "tornando-se parte da minha família e vivendo connosco a partir desse momento" (Kac, 2005: 266). Porém, pouco antes da data agendada de entrega de Alba à família Kac, e perante a polémica que o trabalho do artista vinha suscitando, o laboratório em que a coelha tinha sido produzida recusou-se a entregá-la. Kac, em resposta à recusa do laboratório, fez desfraldar uma bandeira à porta de casa com uma silhueta de uma coelha verde. $\mathrm{O}$ enorme impacto público (à escala global) da criação de Kac, veio abrir as portas dos laboratórios onde, desde há muito, residem criaturas GFP (plantas, peixes, mamíferos). ${ }^{8}$ Trata-se de um marcador genético comum que, quando associado a um gene modificado, por exemplo, revela onde é que o gene modificado se manifesta. Porém, é importante salientar que o marcador genético se transforma, no trabalho de Kac, num marcador simbólico com um alcance insuspeito. O que pode ser avaliado de duas formas. Uma, através da polémica que o projecto suscitou no espaço público global, e outra, através do modo como Kac faz do vasto conjunto de inscrições e implicações éticas, sociais, e políticas, uma parte muito significativa do projecto, a chamar-nos afinal a atenção para a sua dimensão fortemente performativa e reflexiva. Assim, escreve Kac:

A arte transgénica [...] oferece um conceito de estética que enfatiza o social em vez dos aspectos formais da vida e da biodiversidade, que desafia noções de pureza genética, que incorpora trabalho preciso relativamente ao genoma, e que revela a fluidez do conceito de espécie num contexto social cada vez mais transgénico.

Enquanto artista transgénico, eu estou interessado, não na criação de objectos genéticos, mas na invenção de sujeitos sociais transgénicos. Por outras palavras, o que é importante é o processo completamente integrado de criação da coelha; trazê-la para a sociedade em sentido alargado; e providenciar-lhe um meio acolhedor no qual ela

\footnotetext{
${ }^{8}$ Assinale-se que o ano de 2003 assistiu, pela primeira vez, à comercialização em massa de um animal geneticamente modificado com fins estritamente domésticos. O primeiro pet transgénico foi assim o GloFish, o patenteado peixe zebra fluorescente (de cor verde, vermelho, e laranja). Apesar das sérias restrições à sua comercialização na Europa, o GloFish é muito popular nos EUA, não havendo, até muito recentemente, quaisquer relatos de problemas ecológicos relativos à sua venda (ver, a este propósito, a página da Wikipedia relativa ao GloFish em $<$ http://en.wikipedia. org/wiki/Glofish $>$ ).
} 
possa crescer com saúde e em segurança. Este processo integrado é importante porque coloca a engenharia genética num contexto social em que a relação entre as esferas do público e do privado é negociada. Noutras palavras, a biotecnologia, o espaço privado da vida familiar e o domínio social da opinião pública são discutidos por relação uns com os outros. [...] Integrando as lições da filosofia dialógica e da etologia cognitiva, a arte transgénica deve promover a consciência da vida espiritual (mental) do animal transgénico e o respeito por ela. (Kac, 2005: 270-271)

Dir-nos-á o eventual leitor que tudo isto é fundamentalmente negligenciável dado tratar-se de apreciável (e a vários títulos notável) legitimação teórica e retórica de Kac para um projecto que é, na linha de Virilio, uma espécie de programa Zaratustra aplicado à arte, ou, a sermos fiéis à terminologia de Virilio, uma manifestação de um certo expressionismo niilista e impiedoso que veio afinal a ser uma das traduções mais acabadas do que foram as vanguardas artísticas na modernidade.

Em última análise, é difícil demonstrar de uma vez por todas a negra trivialização que decorre de um pensamento como o de Virilio, dada a riqueza do trabalho deste autor, com formulações como as de "acidente" e "simulação" que são incongruentes com tal trivialização da arte transgénica. Dentro desta lógica, a argumentação de Virilio torna-se mais decisiva, dado que chama a nossa atenção para o facto de muitas das nossas criações tecnológicas e artísticas contemporâneas fazerem inscrever no seu cerne uma ideia (uma meta-representação) de simulação, isto é, solicitarem a produção de dispositivos que nos permitam conhecer e antever as implicações das acções (no caso em apreciação, acções tecnologicamente mediadas). A arte transgénica não escapa, como podemos ver, a este compromisso.

Acresce que é notório que a arte transgénica se instala num território de ambiguidade semântica e de maximização da inquietação pública que torna a dúvida instrumental e produtiva para as suas práticas artísticas e reflexivas. Este território é, sem dúvida, o território de toda a arte, mas aqui, e dada a severidade das propostas que se encontram em jogo quando pensamos nos usos que poderão ser dados às bio-tecno-ciências, a ambiguidade e a inquietação tornam-se especialmente operativas e urgentes para muitos, e Kac não foge a isso.

Parece-me importante reiterar dois aspectos que são decisivos para uma leitura mais densa do fenómeno: em primeiro lugar, a atmosfera ética e política é parte integrante do trabalho de artistas como Kac; em segundo lugar, as práticas dos bio-artistas apoiam-se extensivamente em procedimentos que são comuns em laboratórios de genética e biotecnologia, com fins que julgamos desinteressados, desapaixonados e humanamente necessários, mas 
porém invisiveis - apesar da suposta monitorização e regulação dos programas de bioética em que se sustentarão (ainda que se saiba como é residual o financiamento que é dado à produção de saberes de ordem ética e política que nos permitam regular as bio-tecno-ciências quando o comparamos com o financiamento global dos projectos de investigação nesta área).

$\mathrm{O}$ que Kac vem realizar é uma arte que se define tendo por medida o apuro do presente, fazendo-nos conviver com um mundo que exige problematização e reconstrução. Esta reconstrução é imperiosa porque a deriva biotecnológica é seguramente inescapável e, provavelmente, imparável. O que há de temível está, afinal, a montante da arte, isto é, em modos de investigação e intervenção de que a arte se apropria reflexivamente, devolvendo-os ao espaço público, tornando-os visiveis, fazendo recair sobre esses modos de investigação e intervenção o acento contextual que, supostamente, se lhes subtrai.

Será a performance de Ian Wilmut quando apresentou ao mundo a ovelha Dolly (1997) menos perigosa do que a performance de Kac quando apresentou a sua Alba?

Considere-se, afinal, a seguinte possibilidade: a tecno-ciência no espaço público possui todas as características das artes performativas. As acções de um indivíduo (tecno-cientista) ou grupo de indivíduos (tecno-cientistas) num tempo e lugar precisos (que pode ser um laboratório, uma sala de congressos, um estúdio de televisão, uma conferência de imprensa, uma sala de seminários, um museu, etc.), não podendo ser pensados como o trabalho, serão certamente uma parte importante do trabalho. Mobiliza-se, pois, tempo, espaço, corpo, e relação entre o performer e a audiência, tal como faz qualquer artista performativo. Para a tecno-ciência contemporânea, as formulações científicas em blocos de notas, écrans de computadores, ou os objectos e técnicas em uso, não são aquilo que define a tecno-ciência, tal como as artes performativas não se definem tão-só por inscrições em objectos (como se poderão eventualmente definir a pintura ou a escultura). $A$ arte no século XX tende para a performance (Duchamp é, neste sentido, uma referência), tal como a ciência tende para a performance (a memória e a emblematização de Einstein depende tanto das suas equações como da sua performance no espaço público da cultura euro-americana do século XX). Sabemos, aliás, como uma má performance pode ser desastrosa para um oficiante de uma tecno-ciência tomada como relevante no espaço público. E quanto mais hábil for o performer, mais dramático pode ser o faux-pas, como demonstra o recente caso em torno de James Watson.

A meu ver, e num tempo em que perdemos há muito um eixo (pese embora a nossa nostalgia por tal eixo, centro, ou essência), parece-me 
perigoso conviver com um mundo em que a dimensão performativa da tecno-ciência é apagada do espaço público, mantendo-se numa espécie de limbo em que o inquestionável reencantamento do mundo que as bio-tecnociências e seus efeitos promovem tolda todo e qualquer desempenho crítico.

\section{Referências bibliográficas}

Catts, Oron; Zurr, Ionat (2007), "The Art of the Semi-Living and Partial Life. From Extra Ear to In-Vitro Meat”, in Palmira Fontes da Costa (org.), Ciência e bioarte. Encruzilhadas e desafios éticos. Casal de Cambra: Caleidoscópio, 37-56.

Costa, Alcindo et al. (trad.) (1991), Bíblia sagrada. Lisboa: Difusora Bíblica.

Dawkins, Richard (1976), The Selfish Gene. Oxford: Oxford UP.

D'Andrade, Roy (1995), The Development of Cognitive Anthropology. Cambridge: Cambridge UP.

Deleuze, Gilles (1988), Le pli. Leibniz et le baroque. Paris: Les Édition de Minuit.

Derian, James Der (org.) (1998), The Virilio Reader. Oxford: Blackwell Publishers.

Garcia, José Luís (2007), "A arte de criar novas artes: a bioarte como arquétipo da ascensão das infoartes”, in Palmira Fontes da Costa (org.), Ciência e bioarte. Encruzilhadas e desafios éticos. Casal de Cambra: Caleidoscópio, 93-107.

Gell, Alfred (1998), Art and Agency. An Anthropological Theory. Oxford/New York: Oxford UP.

Gell, Alfred (1999), "The Technology of Enchantment and the Enchantment of Technology”, in Alfred Gell (org.), The Art of Anthropology. Essays and Diagrams. London/New Brunswick: The Athlone Press, 159-86.

Gomart, Emilie (org.) (2007), Genesis. Life at the End of the Information Age. Utrecht: Centraal Museum.

Kac, Eduardo (2005), Telepresence E Bio Art. Networking Humans, Rabbits, E Robots. Michigan: The University of Michigan Press.

Latour, Bruno (1991), Nous n'avons jamais été modernes: essai d'antbropologie symétrique. Paris: Éditions La Découverte.

Lotringer, Sylvère; Virilio, Paul (2005), The Accident of Art. New York: Semiotext(e). Marcus, Greil (1999), Marcas de baton. Uma bistória secreta do século vinte. Lisboa: Frenesi (trad. Helder Moura Pereira).

Stanovich, Keith E. (2004), The Robot's Rebellion. Finding Meaning in the Age of Darwin. Chicago/London: The University of Chicago Press.

Shore, Bradd (1996), Culture in Mind. Cognition, Culture, and the Problem of Meaning. Oxford: Oxford UP.

Sloterdijk, Peter (2007), Regras para o parque bumano. Coimbra: Angelus Novus (trad. Manuel Resende).

Virilio, Paul (2003), Art and Fear. London/New York: Continuum (trad. Julie Rose). 